\title{
Serum hepatic biochemistry and electrophoretic protein profile of healthy and Ehrlich tumor-bearing mice treated with extracts of Agaricus blazei Murill
}

\section{Bioquímica hepática sérica e perfil proteico eletroforético de camundongos saudáveis ou portadores do tumor de Ehrlich tratados com frações de extratos de Agaricus blazei Murril}

\author{
Durval Verçosa Junior ${ }^{1}$; Neide Judith Faria de Oliveira'²; Eduardo Robson Duarte ${ }^{3}$; \\ Gabriela Almeida Bastos ${ }^{4}$; Ana Cláudia Maia Soares ${ }^{5}$; Geovanni Dantas Cassali ${ }^{6}$; \\ Benito Soto-Blanco ${ }^{7}$; Marília Martins Melo ${ }^{8 *}$
}

\begin{abstract}
Compounds isolated from Agaricus blazei Murill represent a group of promising natural immunomodulators for use in the treatment of neoplasms. We have evaluated the serum biochemical profile of healthy and Ehrlich tumor-bearing mice treated with different extracts of $A$. blazei. Total, supernatant, and polysaccharide extracts of $A$. blazei were obtained from suspensions (at acidic or neutral $\mathrm{pH}$ ) kept in a water bath at $60^{\circ} \mathrm{C}$ or in an ultrasonic bath at $37^{\circ} \mathrm{C}$. After oral administering the extracts to mice for 21 days, blood samples were collected for determination of aspartate aminotransferase (AST), alanine aminotransferase (ALT), creatine kinase (CK), urea, total protein, albumin, globulins, and alpha-, beta- and gamma-globulin fractions. The presence of the tumor led to a significant increase in serum CK and AST activities and in the concentrations of total globulin and the gamma-globulin fraction, and to a decrease in the albumin and alpha2-globulin levels. The polysaccharide extracts of $A$. blazei reduced the serum AST and ALT activities, probably due to a hepatoprotective effect. In addition, polysaccharide and supernatant extracts inhibited the tumor-induced increase in gamma-globulin levels. Thus, the supernatant and polysaccharide fractions of the extract of $A$. blazei have potential for use in complementary antineoplastic treatments.
\end{abstract}

Key words: Agaricaceae. Agaricales. Sun mushroom. Extracts. Polysaccharides. Antitumor.

\section{Resumo}

Biocompostos de Agaricus blazei Murril representam imunomoduladores naturais promissores para uso no tratamento de neoplasias. Objetivou-se avaliar o perfil bioquímico hepático sérico camundongos

\footnotetext{
${ }^{1}$ Prof. Dr., Assistente, Pontifícia Universidade Católica de Minas Gerais, PUC, Belo Horizonte, MG, Brasil. E-mail: durvalvet@ gmail.com

2 Prof ${ }^{\mathrm{a}} \mathrm{Dr}^{\mathrm{a}}$ Adjunto, Instituto de Ciências Agrárias, Universidade Federal de Minas Gerais, UFMG, Montes Claros, MG, Brasil. E-mail: neideufmg@gmail.com

${ }^{3}$ Prof. Dr. Adjunto, Instituto de Ciências Agrárias, UFMG, MG, Brasil. E-mail: duartevet@hotmail.com

${ }^{4}$ Mestre, Instituto de Ciências Agrárias, UFMG, MG, Brasil. E-mail: gabi_bastos@ymail.com

${ }^{5}$ Mestre, Instituto de Ciências Agrárias, UFMG, Montes Claros, MG, Brasil. E-mail: aninha_maiamoc@yahoo.com.br

${ }^{6}$ Prof. Dr. Titular, Instituto de Ciências Biológicas, Universidade Federal de Minas Gerais, UFMG, Belo Horizonte, MG, Brasil. E-mail: cassalid@icb.ufmg.br

${ }^{7}$ Prof. Dr. Associado, Escola de Veterinária, UFMG, Belo Horizonte, MG, Brasil. E-mail: benito@ufmg.br

${ }^{8}$ Prof $^{\text {a }}$ Dr $^{\text {a }}$ Titular, Escola de Veterinária, UFMG, Belo Horizonte, MG, Brasil. E-mail: mariliamm@ufmg.br

* Author for correpondence
} 
saudáveis ou portadores do tumor de Ehrlich tratados com diferentes extratos de A. blazei. Em pH ácido ou neutro e sob temperatura de extração de $60{ }^{\circ} \mathrm{C}$ em banho-maria ou $37^{\circ} \mathrm{C}$ em banho ultrassônico foram obtidos extratos totais, de sobrenadante e de polissacarídeos de A. blazei. Após administração oral dos tratamentos para camundongos por 21 dias foram realizadas coletas de sangue e determinadas as atividades de aspartato aminotransferase (AST), alanina aminotransferase (ALT), creatina quinase (CK) e as concentrações de ureia, proteína total, albumina, globulinas e frações alfa, beta e gamaglobulina. A presença do tumor de Ehrlich foi responsável por aumento significativo nas atividades séricas de AST e CK e das concentrações de globulinas totais e da fração gama-globulina, além de redução dos níveis de albumina e das alfa2-globulinas. Os extratos de polissacarídeos de $A$. blazei reduziram as atividades séricas de AST e ALT, provavelmente devido a um efeito hepatoprotetor. Além disto, extratos de polissacarídeos e sobrenadante inibiram o aumento das gama-globulinas induzido pelo tumor. Assim, as frações de polissacarídeos e sobrenadante do extrato de $A$. blazei apresentam bom potencial para uso complementar ao tratamento antineoplásico.

Palavras-chave: Agaricaceae. Agaricales. Cogumelo do sol. Extratos. Polissacarídeos. Antineoplásico.

\section{Introduction}

Agaricus blazei Murill, commonly known as sun mushroom, is a basidiomycete belonging to the order Agaricales and family Agaricaceae. It is native to Brazil, but has been produced and marketed in both Brazilian and international markets (WASSER et al., 2002). Biologically active compounds from A. blazei show great potential for use in anticancer therapy (BERVEN et al., 2015). The activity of $\beta$-1,6-glucan, $\beta$-1,3-glucan, active hemicellulose compound, and antitumor organic substance mie of A. blazei when used as adjuvants in the treatment of neoplasms was observed as an elevation in the titers of $\mathrm{M}$ and $\mathrm{G}$ immunoglobulins and in the concentration of interleukin-1, accompanied by an increased number and activity of natural killer cells (ITHO et al., 1997; OHNO et al., 2001; TAKESHI et al., 2001; OSHIMAN et al., 2002).

Some of the functional compounds from $A$. blaze $i$ are inside the cell wall (FIRENZUOLI et al., 2008; BIEDRON et al., 2012). Therefore, greater disruption of the cells may increase adjuvant activity against cancers by releasing additional compounds. Different forms of extraction with acidification or denaturing of hemicellulose by ultrasonic waves could also enhance the anticancer activity. Thus, we aimed to evaluate the effect of different extracts and components of A. blazei on liver biochemistry and serum protein profiles (electrophoresis) of healthy and Ehrlich tumor-bearing mice.

\section{Materials and Methods}

Extracts were obtained from $3.0 \mathrm{~kg}$ of $A$. blazei purchased from a producer from São José do Rio Preto, SP, Brazil. After morphological and DNA sequence identification, samples were deposited in the herbarium of the Institute of Biological Sciences, Federal University of Minas Gerais (UFMG BHCB 97946). Mushrooms (600 g) were desiccated and crushed through 40 mesh for aqueous extraction and fractionation as described below.

Aliquots of $150 \mathrm{~g}$ were mixed in $1,000 \mathrm{~mL}$ of distilled water or glacial acetic acid at $2 \%$ $\mathrm{w} / \mathrm{v}$, resulting in suspensions at $\mathrm{pH} 7$ and $\mathrm{pH} 4$, respectively. The process was repeated and 1,000 $\mathrm{ml}$ of each suspension was kept in a water bath at $60{ }^{\circ} \mathrm{C}$ for $3 \mathrm{~h}$ or in an ultrasonic bath at $37{ }^{\circ} \mathrm{C}$ for $30 \mathrm{~min}$. The suspensions were filtered and the $\mathrm{pH}$ was confirmed. Four aqueous extracts were thus obtained: two from the water bath, one a neutral solution ( $\mathrm{pH} 7)$ and the other an acid $(\mathrm{pH} \mathrm{4)}$, and two from the ultrasonic bath, one a neutral solution $(\mathrm{pH} 7)$ and the other an acid $(\mathrm{pH} 4)$.

Aliquots of $500 \mathrm{~mL}$ of each extract were mixed with $2,000 \mathrm{~mL}$ of ethanol to precipitate polysaccharides. After the precipitation, $50 \mathrm{~mL}$ of each solution was placed in a Falcon tube and centrifuged at $20^{\circ} \mathrm{C}$ and $450 \times g$ for $10 \mathrm{~min}$. The precipitate was dried at room temperature, weighed, and the percentage of polysaccharides calculated. 
The precipitates were re-suspended in $500 \mathrm{~mL}$ distilled water or acetic acid solution to obtain polysaccharide solutions of $A$. blazei aqueous extracts. The supernatants were concentrated on a rotary evaporator at $80^{\circ} \mathrm{C}$ to remove the ethanol fraction. Distilled water or acid solution were added to the remaining supernatant to a $500 \mathrm{~mL}$ volume and designated as the supernatant solutions of $A$. blazei extracts. The original solution, polysaccharide solutions, and supernatant solutions were evaluated for each extract, giving a total of twelve extract solutions. Two control solutions (without fungi) were also tested. A chart illustrating the derivation of the extracts is shown in Figure 1.

Figure 1. Extracts of Agaricus blazei Murrill used in this study.

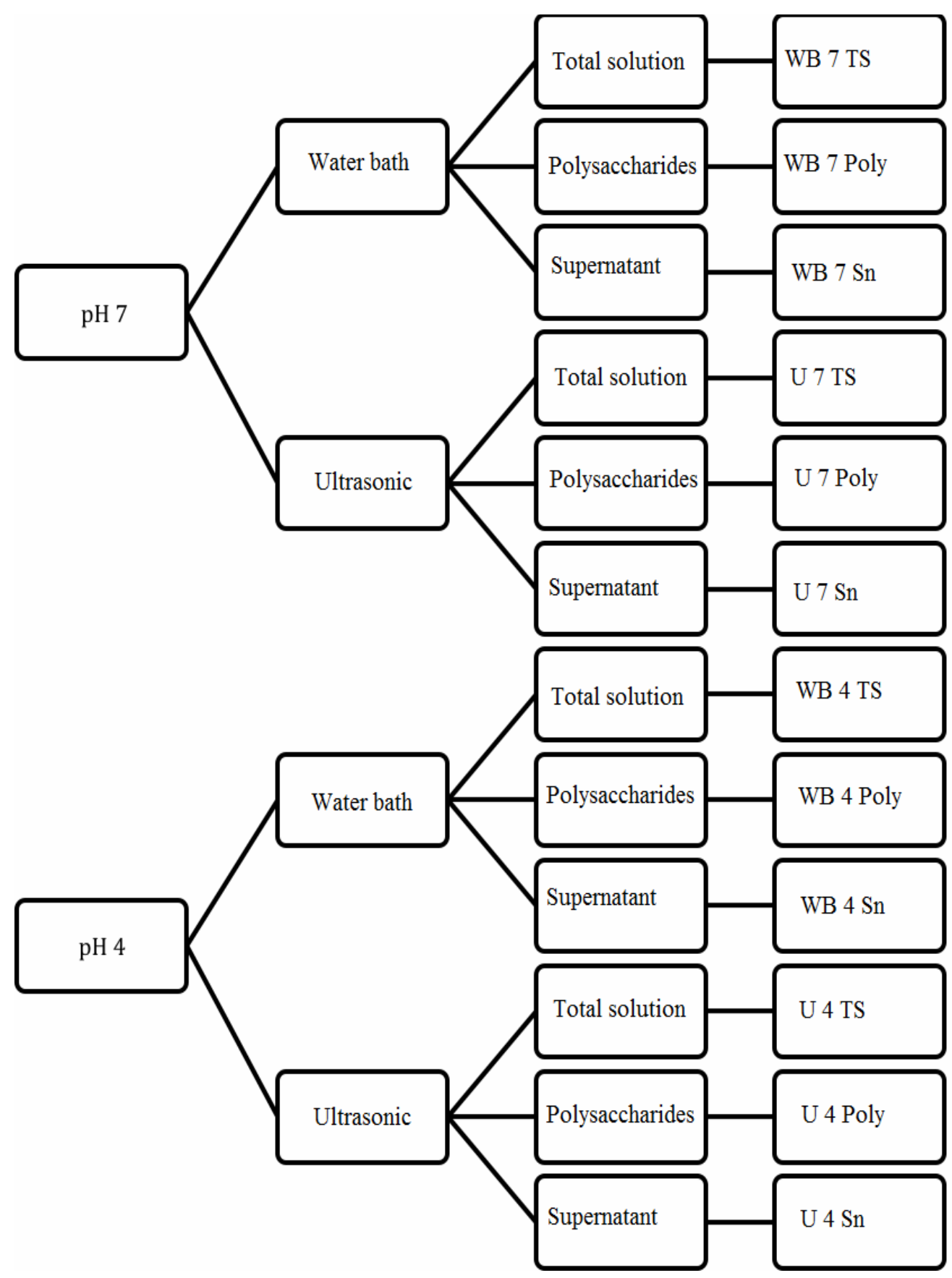


The subjects were 192 60-day old nonisogenic female mice of Swiss lineage, weighing 30-45 $\mathrm{g}$; they were obtained from the animal house of Ezequiel Dias Foundation, Belo Horizonte, MG The experimental protocol was approved by the ethics committee for animal experimentation of UFMG (certificate number 34/2006).

The mice were randomly divided into four groups of 48 animals corresponding to the four extraction methods. For each type of extraction there were two groups of 24 animals, with and without tumors, designated as Group I (GI) and Group II (GII), respectively. These groups were further divided into four subgroups of six animals each. The groups of six animals were kept in cages $(40 \times 45 \times 25 \mathrm{~cm})$ for 10 days for adaptation prior to the experiment. The animals received either the total extract, the polysaccharide solution, the supernatant solution, or distilled water orally for 21 days.

For solid tumor induction, the carcinogenic cells were maintained in ascitic form in Swiss albino mice and were transferred weekly to healthy animals to preserve the Ehrlich tumor in vivo. On day seven post-inoculation, $3.0 \mathrm{~mL}$ of ascitic fluid was collected in sterile disposable syringe from donor mice. This fluid was placed in a Falcon tube and centrifuged at $300 \times g$ for 3 . The supernatant was removed, $3.0 \mathrm{~mL}$ of $0.9 \%$ saline solution at room temperature was added, and the procedure was repeated three times until the supernatant became translucent.

For analysis of tumor viability, $2.0 \mathrm{~mL}$ saline was added to $0.02 \mathrm{~mL}$ of cell suspension. After homogenization, $0.1 \mathrm{~mL}$ aliquot of this mixture was added to an equal volume of $1 \%$ trypan blue. The viable cell count was performed using the external Neubauer hemocytometer quadrants. The viable (translucent) cells made up $95.04 \%$ of the sample, while $4.69 \%$ were non-viable (stained blue), giving a value of $5 \times 10^{8}$ viable tumor cells per $\mathrm{mL}$ of suspension.

All mice were treated once per day for 21 days with distilled water or extracts after three hours of water and food fasting. Solutions were administered $(0.5 \mathrm{~mL})$ by gavage at a dose of $2.5 \mathrm{~g} / \mathrm{kg}$ body weight.
On the $10^{\text {th }}$ day, $50 \mu \mathrm{L}$ of tumor cell suspension was injected into the footpad of the left hind limb of GII mice. After 21 days the animals were anesthetized with ketamine $(50 \mathrm{mg} / \mathrm{g})$ and xylazine $(10 \mathrm{mg} / \mathrm{g})$ intramuscularly and $1 \mathrm{~mL}$ of blood was collected without anticoagulant from each animal.

The serum was stored at $-20^{\circ} \mathrm{C}$, and later tested for aspartate aminotransferase (AST), alanine aminotransferase (ALT), total creatine kinase (CK), and urea by an enzymatic method with specific commercial kits (Bioclin, Belo Horizonte, MG, Brazil). Signals were measured with a biochemical analyzer (TP Analyzer, Thermoplate, China). The total protein concentration was calculated by refratometer (Ningbo Utech International $\mathrm{CO}$ LTD) and the fractioned proteins (albumin, alfa, beta and gamma globulins) were evaluated by eletrophoresis in agarose gel (CELMGEL) (30 min) in TRIS buffer. The gels were stained for 5 minutes in $200 \mathrm{~mL}$ of Amido black and destained in acid acetic solution (7\%) until the gel background was completely clear. The concentration of protein fractions was determined by the use of computerassisted software CELM SE- 250.

The normality of variables was tested by the Kolmogorov-Smirnov test. The parametric variables were subjected to analysis of variance (ANOVA) and the means were compared with Duncan's test with significance set at 5\% significance. Nonparametric data were analyzed with the Kruskal-Wallis test.

\section{Results and Discussion}

The serum activities of AST, ALT, and CK, and the urea levels are shown in Table 1 . The presence of the Ehrlich tumor caused a significant increase in serum AST of mice, whether or not they were treated with $A$. blazei extracted in a water bath at $60^{\circ} \mathrm{C}$ at either $\mathrm{pH}$, except for the group treated with the polysaccharide solution that was extracted from $A$. blazei at pH 4 (GII-WB7Poly). These liver metabolic changes may be the result of high circulating levels of decarboxylase-inducing factors, interleukin 1 (IL-1) and tumor necrosis factor (TNF- $\alpha$ ), secreted by the tumor (KOREKANE et al., 2003). 
Table 1. Means and standard deviations of aspartate aminotransferase (AST), alanine aminotransferase (ALT), creatine kinase (CK), and urea in serum of healthy rats (GI) or carriers of solid Ehrlich tumor (GII) treated with water (Cont), total solution (TS), polysaccharides (Poly), and supernatant ( $\mathrm{Sn}$ ) of extracts of Agaricus blazei Murill obtained at $\mathrm{pH}$ 7 or 4 from a water-bath at $60{ }^{\circ} \mathrm{C}$ or ultrasonic bath at $37^{\circ} \mathrm{C}$

\begin{tabular}{|c|c|c|c|c|c|c|c|c|c|}
\hline \multirow{2}{*}{$\begin{array}{l}\text { Solution } \mathbf{p H} \\
\text { Extraction in }\end{array}$} & \multirow{2}{*}{$\begin{array}{c}\text { Groups } \\
\text { vater-bath at }\end{array}$} & \multicolumn{2}{|l|}{ AST (U/I) } & \multicolumn{2}{|l|}{$\operatorname{ALT}(\mathbf{U} / \mathbf{l})$} & \multicolumn{2}{|l|}{ CK (U/I) } & \multicolumn{2}{|l|}{ Urea (mg/dl) } \\
\hline & & $0^{\circ} \mathrm{C}$ & & & & & & & \\
\hline \multirow{8}{*}{7} & GI-Cont & $178.25 \pm 125.95$ & $\mathrm{c}$ & $102.63 \pm 43.98$ & a & $463.88 \pm 559.28$ & $\mathrm{~b}$ & $62.38 \pm 3.58$ & de \\
\hline & GI-ST & $141.50 \pm 57.46$ & c & $39.83 \pm 15.52$ & b & $256.33 \pm 268.15$ & b & $58.67 \pm 23.53$ & e \\
\hline & GI-Poly & $125.0 \pm 102.19$ & c & $29.17 \pm 21.69$ & b & $442.00 \pm 430.09$ & b & $69.17 \pm 30.14$ & de \\
\hline & GI-Sn & $216.00 \pm 29.15$ & c & $100.33 \pm 76.14$ & a & $453.33 \pm 247.08$ & b & $60.33 \pm 27.11$ & e \\
\hline & GII-Cont & $567.83 \pm 940.11$ & a & $134.42 \pm 29.11$ & $\mathrm{a}$ & $805.83 \pm 663.52$ & a & $74.42 \pm 9.28$ & de \\
\hline & GII-ST & $305.67 \pm 48.93$ & $\mathrm{a}$ & $136.00 \pm 22.12$ & a & $1537.17 \pm 1574.86$ & a & $80.33 \pm 8.69$ & d \\
\hline & GII-Poly & $327.67 \pm 16.95$ & a & $156.17 \pm 24.73$ & a & $1666.00 \pm 1033.28$ & a & $74.17 \pm 7.14$ & de \\
\hline & GII-Sn & $305.17 \pm 34.64$ & a & $154.17 \pm 39.23$ & a & $568.00 \pm 388.47$ & $\mathrm{~b}$ & $61.17 \pm 16.57$ & e \\
\hline \multirow{8}{*}{4} & GI-Cont & $178.25 \pm 125.95$ & b & $102.63 \pm 43.98$ & a & $463.88 \pm 559.28$ & a & $62.38 \pm 3.58$ & e \\
\hline & GI-ST & $134.83 \pm 45.88$ & $\mathrm{~b}$ & $91.33 \pm 9.05$ & a & $107.17 \pm 70.31$ & a & $82.83 \pm 18.95$ & de \\
\hline & GI-Poly & $123.67 \pm 92.86$ & $\mathrm{~b}$ & $85.67 \pm 29.92$ & a & $382.00 \pm 336.26$ & a & $90.00 \pm 18.23$ & de \\
\hline & GI-Sn & $162.00 \pm 87.33$ & $\mathrm{~b}$ & $119.17 \pm 45.32$ & a & $783.00 \pm 1028.76$ & a & $104.17 \pm 30.65$ & d \\
\hline & GII-Cont & $567.83 \pm 940.11$ & a & $134.42 \pm 29.11$ & a & $805.83 \pm 663.52$ & a & $74.42 \pm 9.28$ & e \\
\hline & GII-ST & $323.17 \pm 108.36$ & a & $127.67 \pm 35.18$ & a & $204.67 \pm 214.22$ & a & $63.17 \pm 9.24$ & e \\
\hline & GII-Poly & $268.83 \pm 34.71$ & ab & $131.00 \pm 39.03$ & a & $105.50 \pm 35.88$ & a & $69.67 \pm 13.97$ & e \\
\hline & GII-Sn & $300.00 \pm 88.42$ & a & $138.17 \pm 71.10$ & a & $488.83 \pm 681.13$ & a & $67.50 \pm 12.37$ & e \\
\hline \multicolumn{10}{|c|}{ Extraction in ultrasonic bath at $37^{\circ} \mathrm{C}$} \\
\hline \multirow{8}{*}{ 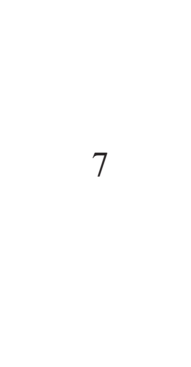 } & GI-Cont & $178.25 \pm 125.95$ & ab & $102.63 \pm 43.98$ & a & $463.88 \pm 559.28$ & a & $62.38 \pm 3.58$ & def \\
\hline & GI-ST & $369.50 \pm 290.88$ & a & $126.50 \pm 60.49$ & a & $1093.33 \pm 1498.00$ & a & $54.83 \pm 4.88$ & ef \\
\hline & GI-Poly & $173.33 \pm 66.36$ & $\mathrm{~b}$ & $73.17 \pm 33.8$ & a & $142.33 \pm 53.66$ & a & $46.17 \pm 16.19$ & f \\
\hline & GI-Sn & $277.33 \pm 108.48$ & ab & $93.50 \pm 36.10$ & a & $570.83 \pm 528.69$ & a & $47.00 \pm 16.33$ & f \\
\hline & GII-Cont & $567.83 \pm 940.11$ & a & $134.42 \pm 29.11$ & a & $805.83 \pm 663.52$ & a & $74.42 \pm 9.28$ & d \\
\hline & GII-ST & $279.33 \pm 29.15$ & ab & $110.00 \pm 22.36$ & a & $138.83 \pm 80.73$ & a & $49.55 \pm 16.78$ & def \\
\hline & GII-Poly & $313.50 \pm 86.95$ & ab & $108.50 \pm 22.78$ & a & $216.67 \pm 246.32$ & a & $60.50 \pm 13.55$ & ef \\
\hline & GII-Sn & $357.17 \pm 161.19$ & a & $129.67 \pm 65.58$ & a & $646.67 \pm 518.58$ & a & $67.00 \pm 30.47$ & de \\
\hline \multirow{8}{*}{4} & GI-Cont & $176.25 \pm 125.95$ & a & $102.63 \pm 43.98$ & $\mathrm{abc}$ & $463.88 \pm 559.28$ & ab & $62.38 \pm 3.58$ & de \\
\hline & GI-ST & $187.17 \pm 120.24$ & a & $62.50 \pm 38.52$ & c & $229.17 \pm 221.29$ & ab & $31.33 \pm 16.72$ & f \\
\hline & GI-Poly & $259.00 \pm 100.54$ & a & $90.17 \pm 28.29$ & bc & $534.83 \pm 462.11$ & ab & $45.00 \pm 7.77$ & ef \\
\hline & GI-Sn & $215.33 \pm 133.73$ & a & $79.50 \pm 60.36$ & c & $277.50 \pm 316.30$ & ab & $51.33 \pm 40.21$ & ef \\
\hline & GII-Cont & $567.83 \pm 940.11$ & a & $134.42 \pm 29.11$ & ab & $805.83 \pm 663.52$ & a & $74.42 \pm 9.28$ & d \\
\hline & GII-ST & $421.67 \pm 192.20$ & a & $142.50 \pm 46.63$ & a & $363.33 \pm 242.40$ & ab & $64.33 \pm 29.84$ & de \\
\hline & GII-Poly & $310.67 \pm 62.15$ & a & $101.17 \pm 33.56$ & $\mathrm{abc}$ & $180.00 \pm 145.84$ & ab & $50.50 \pm 14.10$ & ef \\
\hline & GII-Sn & $251.67 \pm 37.76$ & a & $91.00 \pm 21.60$ & $\mathrm{bc}$ & $101.33 \pm 65.27$ & $\mathrm{~b}$ & $50.17 \pm 6.46$ & ef \\
\hline
\end{tabular}

a,b,c Different letters in the same column, bath and $\mathrm{pH}$ indicate significant differences $(\mathrm{p}<0.05)$, test of Kruskal-Wallis

de,, Different letters in the same column, bath and $\mathrm{pH}$ indicate significant differences $(\mathrm{p}<0.05)$, ANOVA followed by Duncan test. 
On the other hand, for the mice treated with $A$. blazei extracted in an ultrasonic bath at $\mathrm{pH} 7$, those without tumors treated with the polysaccharide solution (GI-U7Poly) had significantly lower AST than those treated with total solution, the tumorbearing untreated mice (GII-Control), and the tumor-bearing mice treated with supernatant (GIIU7Sn). In the latter two subgroups, GII-Control and GII-U7Sn, Ehrlich's tumor may have contributed to the elevation of AST. For the mice treated with extracts produced in the ultrasonic bath at $\mathrm{pH} 4$ there were no statistically significant differences in AST among the different groups ( $p>0.05)$.

Treatments with $A$. blazei extracts have been shown to lead to AST decreases in mice with hepatotoxicity induced by carbon tetrachloride (WU et al., 2011) and in human patients with hepatitis B (HSU et al., 2008). Similarly, a decrease AST was observed for patients with colorectal cancer treated with Agaricus sylvaticus post operatively (COSTA FORTES; GARBI NOVAES, 2011). Moreover, Chang et al. (2012) showed an increase of AST in experiments with female mice treated with $A$. blazei.

Total and polysaccharide extract of A. blazei at $60{ }^{\circ} \mathrm{C}$ and $\mathrm{pH} 7$ reduced ALT activity in healthy mice (GI-WB7TS and GI-WB7Poly). These results corroborate those of Hsu et al. (2008) and Wu et al. (2011), who found that treatment with A. blazei was led to decreased ALT activity in patients with chronic diseases and rats treated with carbon tetrachloride. On the other hand, Chang et al. (2012) found an increase in ALT in experiments with female mice treated with $A$. blazei.

The presence of the Ehrlich tumor caused a significant increase in serum CK activity of mice in the GII-control, GII-WB7TS, and GII-WB7Poly groups and a reduction in the GII-U4Sn group. These changes were probably random.

Healthy mice treated with supernatant of $A$. blazei extracted at $60{ }^{\circ} \mathrm{C}$ at $\mathrm{pH} 4$ (GI-WB4Sn) showed higher serum urea concentrations $(\mathrm{p}<0.05)$ than mice with tumors, independent of treatment with fungi. Furthermore, these levels were reduced in animals without tumors treated with U4TS. The main cause of increased serum urea levels is a decreased renal glomerular filtration, but it may also occur as a result of extra-renal factors such as protein catabolism, a high protein diet, vascular volume depletion, and in response to certain drugs (BRAUN; LEFEBVRE, 2008). Hence, it is possible that treatment with $A$. blazei does not promote significant changes in renal function and the differences are only occasional variations.

Serum concentrations of total protein, albumin, and globulins, and the albumin/globulin ratio are shown in Table 2. Significant differences in the levels of total protein were not observed. In contrast, the levels of albumin in the Ehrlich tumor-bearing animals were significantly decreased. Albumin is considered to be a protein of the negative acute phase. Its serum concentration is reduced in inflammation and chronic disease states (DON; KAYSEN, 2004). Consequently, a reduction of albumin levels can be attributed to the action of the Ehrlich tumor. Furthermore, the WB7Sn, WB4Sn, and U4Poly extracts promoted a reduction of albumin that may be due to liver damage, since the liver is the site of urea synthesis (WORETA; ALQAHTANI, 2014). Other possibilities are that a change may have occurred in the gastrointestinal tract affecting the processes of digestion and absorption of dietary proteins or that there was a loss of albumin in the urine (ECKERSALL, 2008).

Gennari et al. (2002) reported increased levels of $\operatorname{IgG}$ and $\operatorname{IgM}$ in rodents treated with fungi. In the present study, the globulin levels showed occasional increases $(p<0.05)$ that related to tumor presence. Patients with colorectal cancer treated with Agaricus sylvaticus in the postoperative period showed similar values of globulins (COSTA FORTES; GARBI NOVAES, 2011). 
Table 2. Means and respective standard-deviation of total proteins, albumin, globulins, and relation albumin: globulins (A:G) in healthy rats serum (GI) or carriers of solid Ehrlich tumor (GII) treated with water (Cont), total solution (TS), polysaccharides (Poly) and supernatant (Sn) of extracts of Agaricus blazei Murill obtained at pH 7 or 4 from a waterbath at $60^{\circ} \mathrm{C}$ or ultrasonic bath at $37^{\circ} \mathrm{C}$

\begin{tabular}{|c|c|c|c|c|c|c|c|c|c|}
\hline \multirow{2}{*}{$\begin{array}{l}\text { Solution } \mathbf{p H} \\
\text { Extraction in }\end{array}$} & \multirow{2}{*}{$\frac{\text { Groups }}{\text { ater-bath at }}$} & \multicolumn{2}{|c|}{ Total protein $(\mathrm{g} / \mathrm{dl})$} & \multicolumn{2}{|c|}{ Albumin (g/dl) } & \multicolumn{2}{|l|}{ Globulins (g/dl) } & \multicolumn{2}{|c|}{ Relation A:G } \\
\hline & & & & & & & & & \\
\hline \multirow{8}{*}{7} & GI-Cont & $6.28 \pm 0.60$ & a & $4.22 \pm 0.70$ & f & $2.06 \pm 0.52$ & a & $2.22 \pm 0.85$ & a \\
\hline & GI-ST & $5.80 \pm 0.28$ & a & $3.88 \pm 0.70$ & $\mathrm{fg}$ & $1.92 \pm 0.76$ & a & $2.35 \pm 1.03$ & \\
\hline & GI-Poly & $6.12 \pm 0.18$ & a & $4.21 \pm 0.42$ & f & $1.91 \pm 0.45$ & a & $2.52 \pm 0.94$ & a \\
\hline & GI-Sn & $5.90 \pm 0.21$ & a & $3.24 \pm 1.02$ & gh & $2.66 \pm 0.92$ & a & $1.45 \pm 0.82$ & a \\
\hline & GII-Cont & $5.97 \pm 0.32$ & a & $2.98 \pm 1.06$ & gh & $2.74 \pm 0.41$ & a & $1.23 \pm 0.41$ & a \\
\hline & GII-ST & $5.37 \pm 0.29$ & a & $2.81 \pm 0.36$ & $\mathrm{~h}$ & $2.56 \pm 0.36$ & a & $1.13 \pm 0.25$ & a \\
\hline & GII-Poly & $5.53 \pm 0.16$ & a & $2.73 \pm 0.49$ & $\mathrm{~h}$ & $2.80 \pm 0.43$ & a & $1.01 \pm 0.31$ & a \\
\hline & GII-Sn & $5.77 \pm 0.20$ & a & $3.14 \pm 0.18$ & gh & $2.62 \pm 0.16$ & a & $1.20 \pm 0.12$ & a \\
\hline \multirow{8}{*}{4} & GI-Cont & $6.28 \pm 0.60$ & a & $4.22 \pm 0.70$ & f & $2.06 \pm 0.52$ & c & $2.22 \pm 0.84$ & a \\
\hline & GI-ST & $6.07 \pm 0.27$ & a & $3.94 \pm 0.66$ & $\mathrm{fg}$ & $2.13 \pm 0.52$ & c & $2.00 \pm 0.83$ & a \\
\hline & GI-Poly & $5.93 \pm 0.10$ & a & $3.88 \pm 0.45$ & $\mathrm{fg}$ & $2.05 \pm 0.42$ & c & $2.02 \pm 0.73$ & a \\
\hline & GI-Sn & $5.40 \pm 0.28$ & a & $3.46 \pm 0.43$ & gh & $1.94 \pm 0.41$ & c & $1.89 \pm 0.63$ & a \\
\hline & GII-Cont & $5.97 \pm 0.32$ & a & $2.98 \pm 1.06$ & h & $2.74 \pm 0.41$ & b & $1.23 \pm 0.41$ & a \\
\hline & GII-ST & $5.70 \pm 0.24$ & a & $1.76 \pm 0.36$ & h & $3.94 \pm 0.41$ & a & $0.46 \pm 0.15$ & $\mathrm{~b}$ \\
\hline & GII-Poly & $5.33 \pm 0.39$ & a & $3.05 \pm 0.58$ & h & $2.28 \pm 0.31$ & bc & $1.39 \pm 0.46$ & a \\
\hline & GII-Sn & $5.33 \pm 0.39$ & a & $3.15 \pm 0.18$ & $\mathrm{~h}$ & $2.18 \pm 0.24$ & $\mathrm{c}$ & $1.42 \pm 0.16$ & a \\
\hline \multicolumn{10}{|c|}{ Extraction in ultrasonic bath at $37^{\circ} \mathrm{C}$} \\
\hline \multirow{8}{*}{ 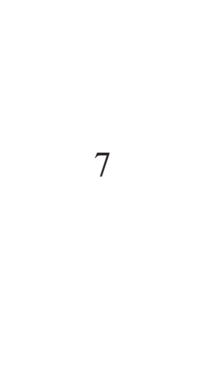 } & GI-Cont & $6.28 \pm 0.60$ & a & $4.22 \pm 0.70$ & f & $2.06 \pm 0.52$ & bc & $2.22 \pm 0.84$ & $\mathrm{a}$ \\
\hline & GI-ST & $6.23 \pm 0.50$ & a & $3.71 \pm 0.76$ & $\mathrm{fg}$ & $2.52 \pm 1.15$ & ab & $1.80 \pm 0.96$ & ab \\
\hline & GI-Poly & $5.83 \pm 0.50$ & a & $3.70 \pm 0.61$ & $\mathrm{fg}$ & $2.13 \pm 0.56$ & bc & $1.78 \pm 0.77$ & ab \\
\hline & GI-Sn & $5.57 \pm 0.39$ & a & $4.15 \pm 0.34$ & f & $1.42 \pm 0.51$ & c & $3.27 \pm 1.22$ & a \\
\hline & GII-Cont & $5.97 \pm 0.32$ & a & $2.98 \pm 1.06$ & gh & $2.74 \pm 0.41$ & ab & $1.23 \pm 0.41$ & ab \\
\hline & GII-ST & $5.30 \pm 0.21$ & a & $2.24 \pm 0.29$ & i & $3.06 \pm 0.38$ & a & $0.75 \pm 0.18$ & $\mathrm{~b}$ \\
\hline & GII-Poly & $5.47 \pm 0.37$ & a & $2.25 \pm 1.06$ & i & $3.22 \pm 1.22$ & a & $1.08 \pm 0.46$ & $\mathrm{ab}$ \\
\hline & GII-Sn & $5.57 \pm 0.23$ & a & $2.72 \pm 0.29$ & hi & $2.85 \pm 0.27$ & ab & $0.97 \pm 0.17$ & $\mathrm{~b}$ \\
\hline \multirow{8}{*}{4} & GI-Cont & $6.28 \pm 0.60$ & a & $4.22 \pm 0.70$ & f & $2.06 \pm 0.52$ & $\mathrm{~cd}$ & $2.22 \pm 0.84$ & a \\
\hline & GI-ST & $5.53 \pm 0.24$ & a & $3.66 \pm 0.54$ & $\mathrm{fg}$ & $1.87 \pm 0.44$ & de & $2.12 \pm 0.89$ & a \\
\hline & GI-Poly & $5.70 \pm 0.33$ & a & $2.96 \pm 0.53$ & hi & $2.74 \pm 0.55$ & ab & $1.33 \pm 0.33$ & a \\
\hline & GI-Sn & $5.10 \pm 0.53$ & a & $3.62 \pm 0.56$ & $\mathrm{fg}$ & $1.48 \pm 0.33$ & e & $2.59 \pm 0.88$ & a \\
\hline & GII-Cont & $5.97 \pm 0.32$ & a & $2.98 \pm 1.06$ & gh & $2.74 \pm 0.41$ & ab & $1.23 \pm 0.41$ & a \\
\hline & GII-ST & $5.53 \pm 0.30$ & a & $2.49 \pm 0.31$ & i & $3.04 \pm 0.20$ & a & $0.83 \pm 0.14$ & a \\
\hline & GII-Poly & $5.53 \pm 0.27$ & a & $2.78 \pm 0.16$ & hi & $2.76 \pm 0.29$ & ab & $1.02 \pm 0.17$ & a \\
\hline & GII-Sn & $5.37 \pm 0.27$ & a & $2.89 \pm 0.59$ & hi & $2.47 \pm 0.69$ & $\mathrm{bc}$ & $1.29 \pm 0.56$ & a \\
\hline
\end{tabular}

a,b,c,d,e Different letters in the same column, bath and $\mathrm{pH}$ indicate significant difference $(\mathrm{p}<0.05)$, by the test of Kruskal-Wallis f,g,h.i Different letters in the same column, bath and $\mathrm{pH}$ indicate significant difference $(\mathrm{p}<0.05)$, ANOVA followed by Duncan test.

Concentrations of the serum fractions of alpha-1, alpha-2, beta, and gamma globulins are shown in Table 3. Serum levels of alpha-1-globulin showed only occasional variations. The levels of alpha-2globulin showed occasional reductions $(\mathrm{p}<0.05)$ related to the presence of tumor. On the other hand, no significant difference was observed in the beta-globulin levels. Additionally, the presence of a tumor caused a statistically significant increase of gamma-globulins in mice treated with water 
and with WB7TS, WB7Sn, WB4TS, U7TS, and all solutions obtained at $\mathrm{pH} 4$ by ultrasonic bath. However, the presence of Ehrlich tumor did not result in significantly increased levels in animals treated with WB7Poly, WB4Poly, WB4Sn, U7Poly, and U7Sn. Thus, the immunomodulatory activity of fungi described previously (BIEDRON et al., 2012) was partially observed in the present study.

Table 3. Means and respective standard-deviation of alfa1, alfa2, beta, and gamma globulins in healthy rat serum (GI) or carriers of solid Ehrlich tumor (GII) treated with water (Cont), total solution (TS), polysaccharides (Poly) and supernatant ( $\mathrm{Sn}$ ) of extracts of Agaricus blazei Murill obtained at $\mathrm{pH} 7$ or 4 from a water-bath at $60{ }^{\circ} \mathrm{C}$ or ultrasonic bath at $37^{\circ} \mathrm{C}$

\begin{tabular}{|c|c|c|c|c|c|c|c|c|c|}
\hline \multirow{2}{*}{$\begin{array}{c}\text { Solution } \mathbf{p H} \\
\text { Extraction in }\end{array}$} & \multirow{2}{*}{$\begin{array}{c}\text { Groups } \\
\text { ater-bath at } 6\end{array}$} & \multicolumn{2}{|c|}{ Alfa1 (g/dl) } & \multicolumn{2}{|c|}{ Alfa2 (g/dl) } & \multicolumn{2}{|l|}{ Beta (g/dl) } & \multicolumn{2}{|l|}{ Gama (g/dl) } \\
\hline & & & & & & & & & \\
\hline \multirow[t]{8}{*}{ then } & GI-Cont & $0.46 \pm 0.24$ & $a b c$ & $0.77 \pm 0.46$ & a & $0.22 \pm 0.11$ & $\mathrm{e}$ & $0.61 \pm 0.18$ & $\mathrm{f}$ \\
\hline & GI-ST & $0.37 \pm 0.24$ & bc & $0.72 \pm 0.50$ & $\mathrm{a}$ & $0.23 \pm 0.10$ & e & $0.61 \pm 0.16$ & f \\
\hline & GI-Poly & $0.38 \pm 0.20$ & $\mathrm{bc}$ & $0.55 \pm 0.27$ & ab & $0.24 \pm 0.05$ & e & $0.67 \pm 0.22$ & $f$ \\
\hline & GI-Sn & $0.25 \pm 0.08$ & c & $0.37 \pm 0.10$ & ab & $1.39 \pm 0.91$ & e & $0.65 \pm 0.46$ & ef \\
\hline & GII-Cont & $0.61 \pm 0.28$ & ab & $0.28 \pm 0.14$ & $\mathrm{~b}$ & $0.58 \pm 0.29$ & e & $1.21 \pm 0.34$ & e \\
\hline & GII-ST & $0.50 \pm 0.08$ & $a b c$ & $0.20 \pm 0.10$ & $\mathrm{~b}$ & $0.67 \pm 0.51$ & e & $1.19 \pm 0.23$ & e \\
\hline & GII-Poly & $0.59 \pm 0.18$ & $\mathrm{ab}$ & $0.34 \pm 0.10$ & $\mathrm{~b}$ & $0.76 \pm 0.50$ & e & $1.03 \pm 0.29$ & ef \\
\hline & GII-Sn & $0.64 \pm 0.10$ & a & $0.24 \pm 0.07$ & $\mathrm{~b}$ & $0.52 \pm 0.17$ & e & $1.24 \pm 0.11$ & e \\
\hline \multirow{8}{*}{4} & GI-Cont & $0.46 \pm 0.24$ & a & $0.77 \pm 0.46$ & a & $0.22 \pm 0.11$ & e & $0.61 \pm 0.18$ & f \\
\hline & GI-ST & $0.38 \pm 0.13$ & a & $0.66 \pm 0.15$ & ab & $0.43 \pm 0.22$ & e & $0.66 \pm 0.19$ & f \\
\hline & GI-Poly & $0.31 \pm 0.11$ & a & $0.70 \pm 0.24$ & ab & $0.51 \pm 0.24$ & e & $0.52 \pm 0.24$ & f \\
\hline & GI-Sn & $0.33 \pm 0.17$ & a & $0.63 \pm 0.22$ & ab & $0.42 \pm 0.19$ & e & $0.56 \pm 0.11$ & f \\
\hline & GII-Cont & $0.61 \pm 0.28$ & a & $0.28 \pm 0.14$ & c & $0.58 \pm 0.29$ & e & $1.21 \pm 0.34$ & e \\
\hline & GII-ST & $0.66 \pm 0.25$ & a & $0.41 \pm 0.11$ & bc & $0.99 \pm 0.81$ & e & $1.87 \pm 0.59$ & e \\
\hline & GII-Poly & $0.29 \pm 0.10$ & a & $0.69 \pm 0.17$ & ab & $0.52 \pm 0.32$ & e & $0.78 \pm 0.12$ & ef \\
\hline & GII-Sn & $0.41 \pm 0.40$ & a & $0.76 \pm 0.46$ & a & $0.30 \pm 0.10$ & e & $0.71 \pm 0.17$ & ef \\
\hline \multicolumn{10}{|c|}{ Extraction in ultrasonic bath at $37^{\circ} \mathrm{C}$} \\
\hline \multirow[t]{8}{*}{ 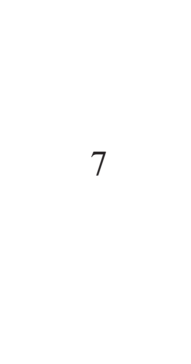 } & GI-Cont & $0.46 \pm 0.24$ & bcd & $0.77 \pm 0.46$ & a & $0.22 \pm 0.11$ & e & $0.61 \pm 0.18$ & f \\
\hline & GI-ST & $0.39 \pm 0.19$ & cd & $0.70 \pm 0.20$ & a & $0.88 \pm 0.91$ & e & $0.55 \pm 0.13$ & f \\
\hline & GI-Poly & $0.36 \pm 0.16$ & d & $0.63 \pm 0.25$ & a & $0.58 \pm 0.49$ & $\mathrm{e}$ & $0.47 \pm 0.21$ & f \\
\hline & GI-Sn & $0.29 \pm 0.07$ & d & $0.34 \pm 0.21$ & a & $0.27 \pm 0.29$ & e & $0.51 \pm 0.10$ & f \\
\hline & GII-Cont & $0.61 \pm 0.28$ & bc & $0.28 \pm 0.14$ & a & $0.58 \pm 0.29$ & $\mathrm{e}$ & $1.21 \pm 0.34$ & $\mathrm{e}$ \\
\hline & GII-ST & $0.69 \pm 0.15$ & $\mathrm{~b}$ & $0.29 \pm 0.12$ & a & $0.44 \pm 0.16$ & $\mathrm{e}$ & $1.65 \pm 0.31$ & e \\
\hline & GII-Poly & $0.66 \pm 0.06$ & $\mathrm{~b}$ & $0.45 \pm 0.40$ & a & $0.76 \pm 0.58$ & e & $0.88 \pm 0.36$ & ef \\
\hline & GII-Sn & $0.95 \pm 0.14$ & a & $0.33 \pm 0.16$ & a & $0.43 \pm 0.25$ & e & $1.13 \pm 0.30$ & ef \\
\hline \multirow{8}{*}{4} & GI-Cont & $0.46 \pm 0.24$ & $\mathrm{ab}$ & $0.77 \pm 0.46$ & a & $0.22 \pm 0.11$ & $\mathrm{e}$ & $0.61 \pm 0.18$ & f \\
\hline & GI-ST & $0.52 \pm 0.13$ & $\mathrm{ab}$ & $0.46 \pm 0.14$ & a & $0.38 \pm 0.27$ & e & $0.51 \pm 0.06$ & f \\
\hline & GI-Poly & $0.49 \pm 0.21$ & $\mathrm{ab}$ & $0.75 \pm 0.44$ & a & $0.67 \pm 0.32$ & e & $0.83 \pm 0.48$ & ef \\
\hline & GI-Sn & $0.33 \pm 0.22$ & $\mathrm{~b}$ & $0.42 \pm 0.13$ & a & $0.28 \pm 0.19$ & $\mathrm{e}$ & $0.45 \pm 0.08$ & f \\
\hline & GII-Cont & $0.61 \pm 0.28$ & a & $0.28 \pm 0.14$ & a & $0.58 \pm 0.29$ & $\mathrm{e}$ & $1.21 \pm 0.34$ & e \\
\hline & GII-ST & $0.71 \pm 0.08$ & a & $0.23 \pm 0.12$ & a & $0.43 \pm 0.25$ & e & $1.67 \pm 0.16$ & e \\
\hline & GII-Poly & $0.65 \pm 0.12$ & a & $0.32 \pm 0.14$ & a & $0.32 \pm 0.12$ & $\mathrm{e}$ & $1.47 \pm 0.32$ & e \\
\hline & GII-Sn & $0.67 \pm 0.15$ & a & $0.24 \pm 0.19$ & a & $0.30 \pm 0.30$ & $\mathrm{e}$ & $1.26 \pm 0.32$ & $\mathrm{e}$ \\
\hline
\end{tabular}

a,b,c,d Different letters in the same column, bath, and $\mathrm{pH}$ indicate significant differences $(\mathrm{p}<0.05)$, ANOVA followed by Duncan's test.

${ }_{\mathrm{e}, \mathrm{f}}$ Different letters in the same column, bath, and $\mathrm{pH}$ indicate significant differences $(\mathrm{p}<0.05)$, Kruskal-Wallis test. 


\section{Conclusions}

The presence of Ehrlich tumor was responsible for significant increases in serum AST and CK activities and total globulin concentrations and gamma globulin fraction, as well as for the reduced levels of albumin and alpha-2-globulins. Polysaccharide extracts of $A$. blazei reduced serum AST and ALT activity, probably due to a liver protective effect. In addition, polysaccharide extracts and supernatant inhibited the increase of gamma-globulin-induced tumor. Consequently, fractions of polysaccharides and supernatant of $A$. blazei extract have good potential for further use in antineoplastic treatments.

\section{Acknowledgements}

This work received financial support from the National Council of Scientific and Technological Development (CNPq), the Foundation for Research Support of Minas Gerais State (FAPEMIG) and the Dean of the Federal University of Minas Gerais (UFMG).

\section{References}

BERVEN, L.; KARPPINEN, P.; HETLAND, G.; SAMUELSEN, A. B. C. The polar high molecular weight fraction of the Agaricus blazei Murill extract, AndoSan ${ }^{\mathrm{TM}}$, reduces the activity of the tumor-associated protease, legumain, in RAW 264.7 cells. Journal of Medicinal Food, New Rochelle, v. 18, n. 4, p. 429-438, 2015.

BIEDRON, R.; TANGEN, J. M.; MARESZ, K.; HETLAND, G. Agaricus blazei Murill immunomodulatory properties and health benefits. Functional Foods in Health and Disease, Dallas, v. 2, n. 11, p. 428-447, 2012.

BRAUN, J.-P.; LEFEBVRE, H. P. Kidney function and damage. In: KANEKO, J. J.; HARVEY, J. W.; BRUSS, M. L. (Ed.). Clinical biochemistry of domestic animals. $6^{\text {th }}$ ed. San Diego: Academic Press, 2008. p. 485-528.

CHANG, J. B.; LU, H. F.; LIAO, N. C.; LEE, C. S.; YEH, M. Y.; LIU, C. M.; CHUNG, M. T.; MAN-KUAN, A.; LIN, J. J.; WU, M. F.; CHUNG, J. G. Evaluation of genotoxicity and subclinical toxicity of Agaricus blazei
Murrill in the Ames test and in histopathological and biochemical analysis. In Vivo, Athens, v. 26, n. 3, p. 437$445,2012$.

COSTA FORTES, R.; GARBI NOVAES, M. R. C. The effects of Agaricus sylvaticus fungi dietary supplementation on the metabolism and blood pressure of patients with colorectal cancer during post surgical phase. Nutrición Hospitalaria, Madrid, v. 26, n. 1, p. 176-186, 2011.

DON, B. R.; KAYSEN, G. Serum albumin: relationship to inflammation and nutrition. Seminar in Dialysis, Cambridge, v. 17, n. 6, p. 432-437, 2004.

ECKERSALL, P. D. Proteins, proteomics, and the dysproteinemias. In: KANEKO, J. J.; HARVEY, J. W.; BRUSS, M. L. (Ed.). Clinical biochemistry of domestic animals. $6^{\text {th }}$ ed. San Diego: Academic Press, 2008. p. 117-155.

FIRENZUOLI, F.; GORI, L.; LOMBARDO, G. The medicinal mushroom Agaricus blazei Murrill: review of literature and pharmaco-toxicological problems. Evidence-Based Complementary and Alternative Medicine, New York, v. 5, n. 1, p. 3-15, 2008.

GENNARI, J.L.; VERONESI, R. GENNARI, M.S. Uso do cogumelo Agaricus sylvaticus como complemento terapêutico em pacientes com câncer de mama e metástase pulmonar. Revista Brasileira de Medicina, v. 59, n. 7, p. 537-538, 2002.

HSU, C.; HWANG, K.; CHIANG, Y.; CHOU, P. The mushroom Agaricus blazei Murrill extract normalizes liver function in patients with chronic hepatitis B. Journal of Evidence-Based Complementary \& Alternative Medicine, Thousand Oaks, v. 14, n. 3, p. 299-301, 2008.

ITHO, H.; SHIMURA, K.; KAWADEM. Antitumor effects of a new polysaccharide-protein complex (ATOM) prepared from Agaricus blazei (Iwade Strain 101) "Himematsutake" and its mechanisms in tumorbearing mice. Anticancer Research, Athens, v. 17, n. 1, p. 277-284, 1997.

KOREKANE, H.; NISHIKAWA, A.; IMAMURA, $\mathrm{K}$. Mechanisms mediating metabolic abnormalities in the livers of Ehrlich tumor-bearing mice. Archives of Biochemistry and Biophysics, New York, v. 412, n. 2, p. 216-222, 2003.

OHNO, N.; FURUKAWA, M.; MINURA, N. N.; ADACHI, Y.; MITOI, M.; YADOMAE, T. Antitumor beta glucano from the cultured fruit body of Agaricus blazei. Biological \& Pharmaceutical Bulletin, Tokyo, v. 24, n. 7, p. 820-828, 2001. 
OSHIMAN, K.; FUJIMIYA, Y.; EBINA, T.; SUZUKI, I.; NOJI, M. Orally administered beta-1,6-D-polyglucose extracted from Agaricus blazei results in tumor regression in tumor-bearing mice. Planta Medica, Stuttgart, v. 68, n. 7, p. 610-614, 2002.

TAKESHI, T.; KIMURA, Y.; OKADA, H. Isolation of an antitumor compound from Agaricus blazei Murrill and its mechanism of action. Journal of Nutrition, Rockville, v. 131, n. 5, p. 1409-1413, 2001.

TELLES, T. C.; MICHEL, A. F. R. M.; LUCIA, M.; MELO, B. M.; BICALHO, A. C. P.; OCARINO, N. M.; MELO, M. M. Evaluation of rat plasma proteins after bothropic venom inoculation and treatment with mesenquimal stem cells. Brazilian Archives of Biology and Technology, Curitiba, v. 57, n. 1, p. 29-36, 2014.
WASSER, S. P.; DIDUKH, M. Y.; AMAZONAS, M. A. L. de; NEVO, E.; STAMETS, P.; EIRA, A. F. Is a widely cultivated culinary-medicinal royal sun agaricus (the himematsutake mushroom) indeed Agaricus blazei Murrill? International Journal of Medicinal Mushrooms, New York, v. 4, n. 1, p. 267-290, 2002.

WORETA, T. A.; ALQAHTANI, S. A. Evaluation of abnormal liver tests. Medical Clinics of North America, Philadelphia, v. 98, n. 1, p. 1-16, 2014.

WU, M. F.; HSU, Y. M.; TANG, M. C.; CHEN, H. C.; CHUNG, J. G.; LU, H. F.; LIN, J. P.; TANG, N. Y.; YEH, C.; YEH, M. Y. Agaricus blazei Murill extract abrogates CCl4-induced liver injury in rats. In Vivo, Athens, v. 25, n. 1, p. 35-40, 2011. 